\title{
Demand controlled ventilation (DCV) in school and office buildings: Lessons learnt from case studies
}

\author{
Bart Merema $^{\mathrm{a}, *}$, Muhannad Delwati $^{\mathrm{b}}$, Maarten Sourbron ${ }^{\mathrm{c}}$, Hilde $^{\text {Breesch }}{ }^{\mathrm{a}}$ \\ ${ }^{a}$ KU Leuven, Department of Civil Engineering, Construction Technology Cluster, Technology Campus Ghent, Belgium \\ ${ }^{\mathrm{b}} \mathrm{KU}$ Leuven, Department of Architectural Engineering, Leuven, Belgium \\ ${ }^{\mathrm{c}} \mathrm{KU}$ Leuven, Mechanical Engineering Technology Cluster, De Nayer Campus, Sint-Katelijne Waver, Belgium
}

\section{A R T I C L E I N F O}

\section{Article history:}

Received 15 January 2018

Revised 25 April 2018

Accepted 27 April 2018

Available online 26 May 2018

\section{Keywords:}

Demand controlled ventilation

Energy savings

IAQ

Ventilation efficiency

Office and school buildings

\begin{abstract}
A B S T R A C T
Demand controlled ventilation (DCV) refers to a ventilation system with air flow rates that are controlled based on a measurement of an indoor air quality (IAQ) and/or on a thermal comfort parameter. DCV operates at reduced air flow rates during a large amount of the operation time and thus consumes less energy for fan operation and heating/cooling the supply air. The aim of the present research is to assess the IAQ ventilation efficiency, and the operation and energy efficiency of real operating DCV systems in moderate climates.

Measurements are carried out for at least two weeks in autumn and winter 2015-2016. The following parameters were monitored: $\mathrm{CO}_{2}$ concentrations and air temperatures at different positions in the room and at the extract air grill, position of the variable air volume (VAV) boxes, supply and extract air flow rates and the occupancy of the room. Four case studies with large and varying occupancy rate and with different use and ventilation systems are selected. Two classrooms and three landscaped offices were evaluated.

The results show that a DCV is interesting in rooms with a large and varying occupancy rate such as lecture rooms and landscaped offices. A good IAQ is measured in all cases studied even at reduced air flow rates. The effect of the reduced air flow on the ventilation efficiency is negligible. The VAV boxes react well to predefined set points for $\mathrm{CO}_{2}$ concentration. During the measurement period, the reduction for fan energy ranges from 25 to $55 \%$ and ventilation heat losses $25-32 \%$ compared to a constant air volume system (CAV) with a design airflow rate of $29 \mathrm{~m}^{3} /$ (h.pers), i.e., IDA3 in EN 13779. However, commissioning of the DCV is necessary to obtain and maintain these performances.
\end{abstract}

(c) 2018 Elsevier B.V. All rights reserved.

\section{Introduction}

European buildings consume approximately $38 \%$ of the total energy consumption (Eurostat, 2014). Of this 38\% total energy consumption, $25 \%$ is consumed by residential and $13 \%$ by nonresidential buildings. In non-residential buildings the end use of energy for heating, ventilation and air-conditioning (HVAC) systems is 50\% [18]. The energy needed for operation of ventilation systems in offices and educational buildings is estimated to be 10$50 \%$ of the total energy consumption in nearly zero energy buildings (nZEB) buildings [7]. To reduce energy consumption in buildings the EPBD directive requires that from 2020 all new buildings in the European Union have to be nZEB buildings. (The Directive 2010/31/EU (EPBD) at Art. 9) The heating demand of buildings is already decreased by increasing the insulation thickness and the

\footnotetext{
* Corresponding author.

E-mail address: bart.merema@kuleuven.be (B. Merema).
}

air tightness of the building envelope. Further reductions can be achieved by optimization of HVAC systems.

One measure to improve the energy efficiency of HVAC systems is the implementation of demand controlled ventilation (DCV), which automatically adapts the air flow rates in relation to the actual ventilation demand, characterized by e.g., occupancy or $\mathrm{CO}_{2}$ concentration. DCV operates at reduced air flow rates during a large amount of the operation time. Due to this decrease, less energy is needed for fan operation and heating/cooling the supply air [3]. Seppänen [21] showed that for further energy reductions in buildings, the application of DCV is an important factor.

The energy saving potential is demonstrated in the studies summarized in Table 1 . In this table the climate region is included to make a distinction between colder and warmer climates. An extensive study with measurements and simulations performed in California [22] showed that DCV combined with air to air heat recovery resulted in the highest reductions for both energy consumption and costs with a maximum of $48 \%$. Especially in rooms 
Table 1

Energy savings for implementing DCV in previous studies.

\begin{tabular}{lllll}
\hline & Fan savings & Heat loss savings & Total energy savings (HVAC) & Climate region [12] \\
\hline Smith and Braun [22] & - & - & $48-52 \%$ & Csb, Csa \\
Stein, Zhou and Cheng [23] & $51-62 \%$ & $34-48 \%$ & - & Csb, Csa \\
Sun, Wang and Ma [24] & $52 \%$ & - & - & Cfa \\
Mysen et al. [17] & - & - & $38 \%$ & Dfc \\
Wachenfeldt et al. [25] & $87 \%$ & $21 \%$ & - & Dfc \\
Maripuu [13] & $50 \%$ & - & - & Dfc \\
Ahmed et al. [1] & - & - & $33-41 \%$ & Dfc \\
\hline
\end{tabular}

with a varying occupancy profile the energy saving potential is significant: maximum 52\%. Stein, Zhou and Cheng [23] showed with measurements of the air flow, during a hot and a cold period for three different locations in California, that the impact of demand control is significant for all-air systems. Fan savings for the three locations were $51-62 \%$ and heating savings $34-48 \%$. Implementing DCV resulted in expected savings of $25 \%$ for the electricity consumption and $41 \%$ on gas consumption used for heating. Sun, Wang and Ma [24], implemented a $\mathrm{CO}_{2}$ based adaptive DCV in a multi-zone office building in Hong-Kong. Fan savings achieved with the DCV strategy were at least $52 \%$ compared with a constant air volume (CAV) system. However, this was only tested for a shorter period time period of 1 day.

The application of DCV has already been studied in colder climates with higher heating demands. Mysen et al. [17] showed that the energy demand in Norwegian school buildings was reduced by $38 \%$ for a $\mathrm{CO}_{2}$-DCV compared with an CAV system. This energy reduction for ventilation was calculated based on measurements of occupancy in 157 classrooms at 81 randomly selected Norwegian schools from March to June 2002. Wachenfeldt et al. [25] showed with measurements and simulations (the analysed period is from 11-17 November 2002) of two school buildings in Norway that the energy demand for heating was reduced by $21 \%$ and the fan energy consumption $87 \%$ compared to a CAV system. Maripuu [13] showed that by implementing a DCV system in a university building with office rooms in Sweden the energy use for the fans was decreased by $50 \%$. These savings were based on annual simulation results. Ahmed et al. [1] showed for the implementation of DCV a decrease of $33-41 \%$ for the energy needed for heating, cooling and fans in an office building with landscaped offices in Finland. The measured landscaped office had a floor area of $380 \mathrm{~m}^{2}$ with a total of 30 work stations. In this study the energy savings for the implementation of DCV are derived from annual simulations. The simulated model was calibrated using measurement data.

The impact of DCV on indoor air quality (IAQ) has been sufficiently studied in the literature. However, most studies mentioned, only focus on the IAQ and not the related energy savings. IAQ is an important factor during the design of the ventilation system. The IAQ affects both the comfort and the health and productivity of the building users [14]. The impact of the air flow rate and the $\mathrm{CO}_{2}$ concentration on the user's performance is equally important with regard to the economic relevance of ventilation. Seppänen, Fisk and Lei [20] combined results of nine studies and concluded that increasing the air flow rate has an impact on the work performance of the user. The effect was at maximum $4 \%$ on the performance rate of the building occupant.

The aforementioned study by Ahmed et al. [1] is one of the few studies combining energy savings and the impact of DCV on IAQ. Here, the measurement results of the $\mathrm{CO}_{2}$ concentration inside the landscaped office indicated a good IAQ with concentrations below $900 \mathrm{ppm}$ during operating hours. In a study of Kolarik et al. [11] field measurements were performed in 4 offices of a refurbished university building with DCV. The installation of DCV during the refurbishment resulted in decreased $\mathrm{CO}_{2}$ concentrations as a result of increased airflow. However, it did not result in statistically significant improvement of perceived IAQ.

Since DCV not only operates at the design air flow rate, there might be an impact on the air distribution inside the room. The air flow pattern is affected due to the lower air flow rates and velocities and might not cover the whole occupied zone. Fisk et al. [8] measured the spatial variability of $\mathrm{CO}_{2}$ concentration in occupied meeting rooms with DCV. In a crowded conference room the $\mathrm{CO}_{2}$ concentration varied for the different measurement positions up to approximately $300 \mathrm{ppm}$ and fluctuated substantially with time for the measurement positions. Measurements for ventilation efficiency in a landscaped office with DCV by Rey Martínez et al. [19] showed values between 0,55 and 0,66. The efficiency was affected by supply air that was mixed with extract air resulting in a higher $\mathrm{CO}_{2}$ concentration at the supply.

Previous studies focused primarily on energy reductions whereas the aim of ventilation is to provide a good IAQ and ventilation efficiency. Additionally, current studies are performed in colder or warmer climates. Nevertheless, data for moderate climates are still missing. The aim of the present research is to assess the IAQ, ventilation efficiency, operation and energy efficiency of real operating DCV systems in a moderate climate. Five rooms with large and varying occupancy profiles in four different school and office buildings in Belgium are selected. Overall conclusions resulting from these case studies are now discussed.

First, a description of the case study buildings and the systems is presented. Afterwards, the measurement setup for the evaluation of IAQ, ventilation efficiency and energy efficiency is shown. Section 4 presents the results of all the measured case studies and finally the conclusions are presented.

\section{Case studies}

This section discusses all the evaluated case studies. A short description is given of the selected case studies. All the case studies analysed are located in Belgium (climate region $\mathrm{Cfb}$ ). Measurements are conducted for over two consecutive weeks during a heating demand period. Case studies are selected based on room type (lecture rooms and landscaped offices) and ventilation system (mechanical balanced and natural supply with mechanical extraction). Other selection criteria were building use and rooms with a large and varying occupancy profile.

Table 2 summarizes the ventilation, room and control properties of the case studies and gives more information about the use. Four different case study buildings are analyzed with 3 different types of rooms:

- classroom

- lecture room

- landscaped offices.

In all the case studies the DCV system is controlled by measured $\mathrm{CO}_{2}$ concentration. With exception of kindergarten "De Boomhut" the ventilation system is also temperature controlled (all-air HVAC). For all the case studies a brief description is given 
Table 2

Building, use, system and control properties for all evaluated case studies.

\begin{tabular}{|c|c|c|c|c|c|c|c|c|c|c|}
\hline Case study & Room type & Floor area & Ventilation system & $\begin{array}{l}\text { Control } \\
\text { parameter } \\
\text { DCV }\end{array}$ & $\begin{array}{l}\text { Air flow } \\
\left(\mathrm{m}^{3} / \mathrm{h}\right)\end{array}$ & $\begin{array}{l}\text { Design air } \\
\text { flow/person } \\
\left(\mathrm{m}^{3} / \mathrm{h}\right)\end{array}$ & $\begin{array}{l}\text { Design } \\
\text { occupancy } \\
\text { (person } / \mathrm{m}^{2} \text { ) }\end{array}$ & $\begin{array}{l}\text { Set point } \\
\text { system }(T)\end{array}$ & $\begin{array}{l}\text { Set point } \\
\text { system }\left(\mathrm{CO}_{2}\right)\end{array}$ & $\begin{array}{l}\text { Measurement } \\
\text { period }\end{array}$ \\
\hline De Boomhut & Classroom & $66 \mathrm{~m}^{2}$ & $\begin{array}{l}\text { Natural air supply } \\
\text { and mechanical } \\
\text { extraction }\end{array}$ & $\mathrm{CO}_{2}$ & $200-550$ & 27,5 & $\begin{array}{l}20 \\
(3,3)\end{array}$ & No set point & 1100 ppm & $\begin{array}{l}16-27 \\
\text { November } 2015\end{array}$ \\
\hline $\begin{array}{l}\text { Test lecture } \\
\text { room }\end{array}$ & Lecture room & $140 \mathrm{~m}^{2}$ & $\begin{array}{l}\text { Balanced mechanical } \\
\text { ventilation } \\
\text { (displacement) }\end{array}$ & $\mathrm{CO}_{2}+\mathrm{T}$ & $400-2200$ & 27,5 & $\begin{array}{l}80 \\
(1,75)\end{array}$ & $21^{\circ} \mathrm{C}$ & $1000 \mathrm{ppm}$ & $\begin{array}{l}8-19 \text { February } \\
2016\end{array}$ \\
\hline Infrax & $\begin{array}{l}\text { Landscaped } \\
\text { office }\end{array}$ & $200 \mathrm{~m}^{2}$ & $\begin{array}{l}\text { Balanced mechanical } \\
\text { ventilation }\end{array}$ & $\mathrm{CO}_{2}+\mathrm{T}$ & $550-1400$ & 70 & $\begin{array}{l}20 \\
(10)\end{array}$ & $22^{\circ} \mathrm{C}$ & $700 \mathrm{ppm}$ & $\begin{array}{l}14 \text { February - } 2 \\
\text { March } 2016\end{array}$ \\
\hline $\begin{array}{l}\text { KU Leuven } \\
\text { office }\end{array}$ & $\begin{array}{l}2 \text { Landscaped } \\
\text { offices }\end{array}$ & $\begin{array}{l}70 \mathrm{~m}^{2} \text { and } \\
72 \mathrm{~m}^{2}\end{array}$ & $\begin{array}{l}\text { Balanced mechanical } \\
\text { ventilation }\end{array}$ & $\mathrm{CO}_{2}+\mathrm{T}$ & $\begin{array}{l}70-420 \\
70-500\end{array}$ & 35 and 42 & $\begin{array}{l}12 \\
12 \\
(6)\end{array}$ & $23,8^{\circ} \mathrm{C}$ & 800 ppm & $\begin{array}{l}25 \text { November - } \\
8 \text { December } \\
2016\end{array}$ \\
\hline
\end{tabular}
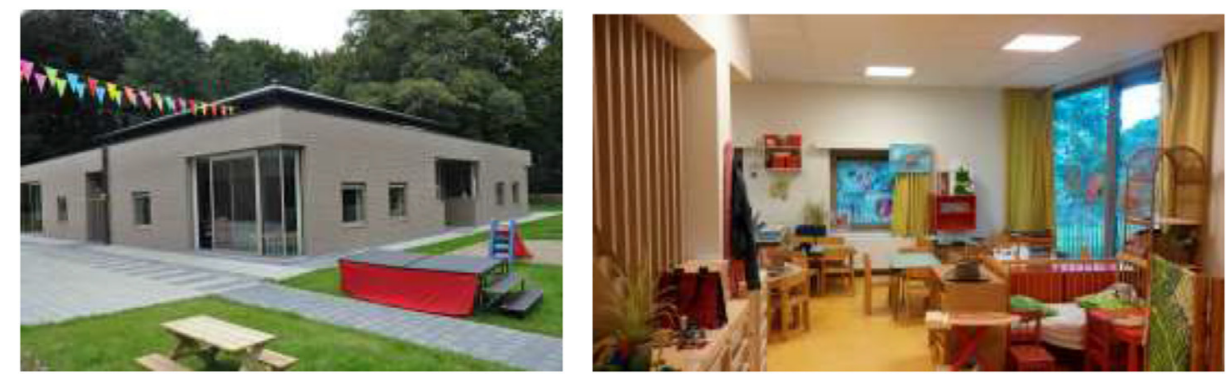

Fig. 1. Left) View of south-east façade of the kindergarten "De Boomhut", right) interior of the classroom.

with the important details. The ventilation system used in the case studies is for three cases a balanced mechanical ventilation. With the exception for the Boomhut which only has a mechanical extraction unit combined with a natural air supply through window grills. The air flow rate, as shown in Table 2, is the design flow rate with both the minimum and maximum air flow rate as specified in the as built files of each case study.

\subsection{Kindergarten De Boomhut}

Kindergarten "De Boomhut" is a school building for pupils between 3 and 6 years old located in Brugge, Belgium. This kindergarten was opened in 2014 and includes four identical rectangular classrooms of each $66 \mathrm{~m}^{2}$. An impression of this building is shown in Fig. 1.

The classrooms used for measurements are located at the north-west side. Fresh air is supplied in each classroom through self-regulating grills above the windows with a maximum supply of $550 \mathrm{~m}^{3} / \mathrm{h}$ at $2 \mathrm{~Pa}$, as indicated in Fig. 2. The air is mechanically extracted by one centrifugal duct fan per two neighboring classrooms with a capacity of $400-1200 \mathrm{~m}^{3} / \mathrm{h}$. The extract air grill in the classroom is located at the mezzanine, just below the ceiling. The extraction air flow rate is controlled by the highest indoor $\mathrm{CO}_{2}$ concentration of the two classrooms, with the set point at $1100 \mathrm{ppm}$. In each classroom a $\mathrm{CO}_{2}$ sensor is placed near the extraction air grill. The $U$-value of the façade is $0,23 \mathrm{~W} / \mathrm{m}^{2} \mathrm{~K}$, roof $0,27 \mathrm{~W} / \mathrm{m}^{2} \mathrm{~K}$ and for the glazing $1,10 \mathrm{~W} / \mathrm{m}^{2} \mathrm{~K}$.

The ventilation system is switched on at $07: 30 \mathrm{~h}$ during weekdays and switched off at 15:30 h except on Wednesdays when the system is switched off at 12:00 $\mathrm{h}$. The classroom is used by approximately 15 pupils during the measurement period. Classes start at $8: 30$ and end at $15: 30 \mathrm{~h}$. No pupils are in the classroom during lunch breaks (12:00-13:30 h). Heating is supplied by three radiators installed near the windows in each classroom. A more detailed description of this case study can be found in Merema et al. [15]. In the case study for the kindergarten de Boomhut also the draught risk is evaluated since natural air supply is used whereby

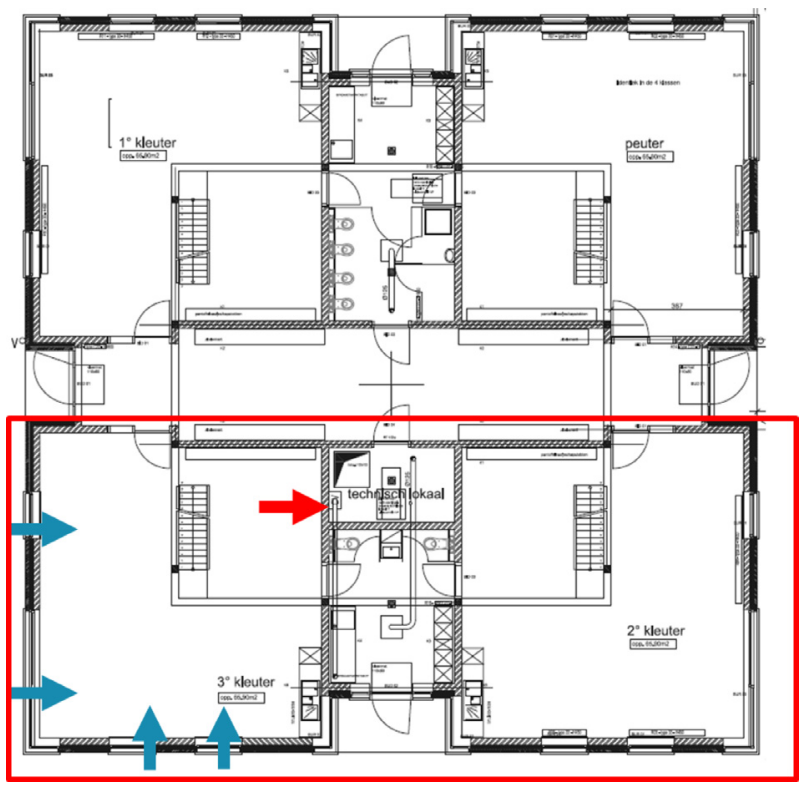

Fig. 2. Plan of the school building, rectangle is the studied zone, blue arrow: supply air grills, red arrow: extract air grill. (For interpretation of the references to color in this figure legend, the reader is referred to the web version of this article.)

the supply air temperature is not controlled. Results showed that the risk of draught in the classroom was small, below 20\% [10]. For detailed results of this measurement see Merema et al. [15].

\subsection{Test lecture rooms KU Leuven}

Fig. 3 shows the outside and inside view of the test lecture rooms located at the Technology Campus Ghent of KU Leuven in Ghent (Belgium). In this case study, the building contains two large lecture rooms with $140 \mathrm{~m}^{2}$ floor area and a maximum occupancy of 80 students each. The building is built in 2014 according to the 

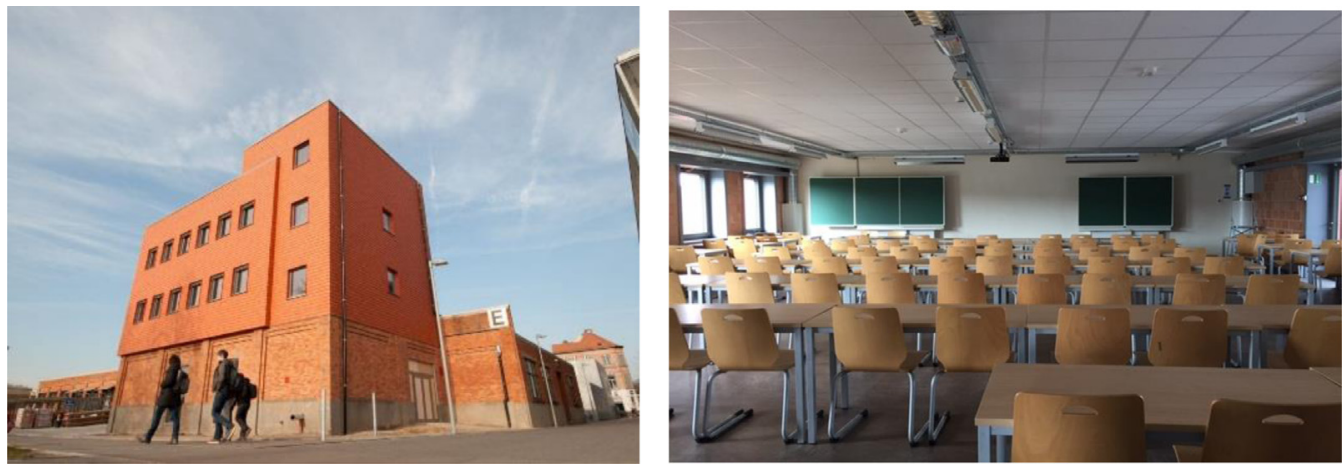

Fig. 3. Left) Outside view of the test building, right) lecture room used for measurements.

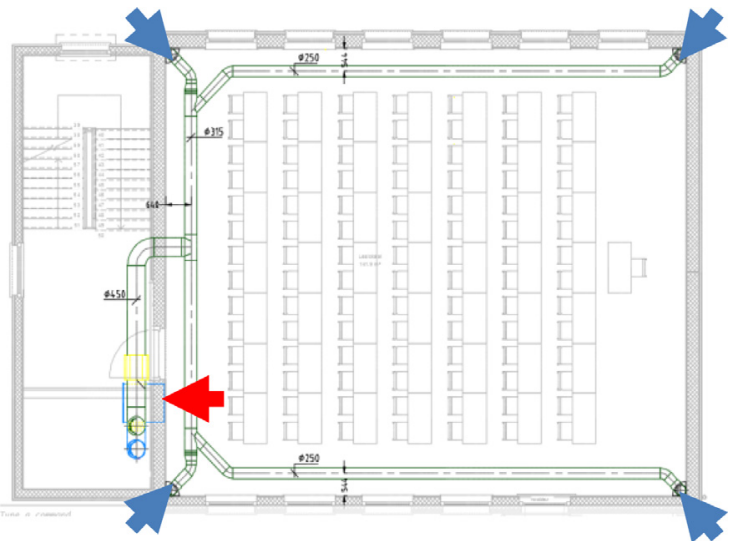

Fig. 4. Plan of the studied lecture room on the first floor, blue is supply air and red extraction air. (For interpretation of the references to color in this figure legend, the reader is referred to the web version of this article.)

Passive House standard, for the design of the building and systems see [2].

Balanced mechanical ventilation is provided with a total airflow supply of $4400 \mathrm{~m}^{3} / \mathrm{h}$ for two lecture rooms. Fresh air is supplied by air diffusers (displacement ventilation) in each corner of the room, as indicated in Fig. 4. The air handling unit (AHU) regulates the VAV dampers by sending a request signal to control the airflow based on $\mathrm{CO}_{2}$ concentrations and operative temperature in the lecture room. Each room is a single zone with a supply and return $\mathrm{VAV}$. Set point for $\mathrm{CO}_{2}$ and indoor temperature (heating) are set at respectively $1000 \mathrm{ppm}$ and $21^{\circ} \mathrm{C}$. During weekdays the AHU is switched on at 7:30 and switched off at 17:30 h.

For heating purposes, the air is preheated by air-to-air heat recovery, i.e. two cross flow plate heat exchangers connected in series with an efficiency of 78\% according to EN 308 (1997). Ad- ditionally, a heating coil of $7.9 \mathrm{~kW}$ is integrated in the supply ducts of each lecture room. A modular bypass is included. A more detailed description of this case study can be found in [16].

\subsection{Office building Infrax}

The office building of Infrax located in Dilbeek (Belgium), shown in Fig. 5, includes 2 landscaped offices per floor, with in total four floors. The building is constructed in 2010 [9]. In one large landscaped office of $200 \mathrm{~m}^{2}$, oriented towards the south east, measurements have been carried out. The average U-value of the building envelope is $0,37 \mathrm{~W} / \mathrm{m}^{2} \mathrm{~K}$ and the air-tightness is: $\mathrm{n}_{50}=1,30$ (1/h).

Balanced mechanical ventilation is provided in which air is supplied by grills in the floor. Each landscaped office is a single zone with a supply VAV and extraction. The supply VAV of the measured zone controls the air flow rate and varies between 550 and $1400 \mathrm{~m}^{3} / \mathrm{h}$ based on the measurement of the $\mathrm{CO}_{2}$ concentration and the operative temperature at the extract air grill. The extract air grill is located at the interior wall central in the office. Set points used for controlling the DCV system are set at $700 \mathrm{ppm}$ and $22{ }^{\circ} \mathrm{C}$. Operating hours for the AHU are from 7:00 to 18:00 h. For heating and cooling the building uses a thermal activated building system (TABS) in addition decentral air heating/cooling coils have been installed to meet the changing demands over a short timeperiod.

\subsection{Office building KU Leuven}

The office building for the administration and logistics department is located in Leuven (Belgium) and shown in Fig. 7. The building consists of two upper floors with open landscaped offices and meeting rooms upon two floors for the servers and a supercomputer. In total, 38 zones are controlled in this building by a central AHU which controls the air flow rate in each zone. The average $U$-value of the building envelope is $0,38 \mathrm{~W} / \mathrm{m}^{2} \mathrm{~K}$.
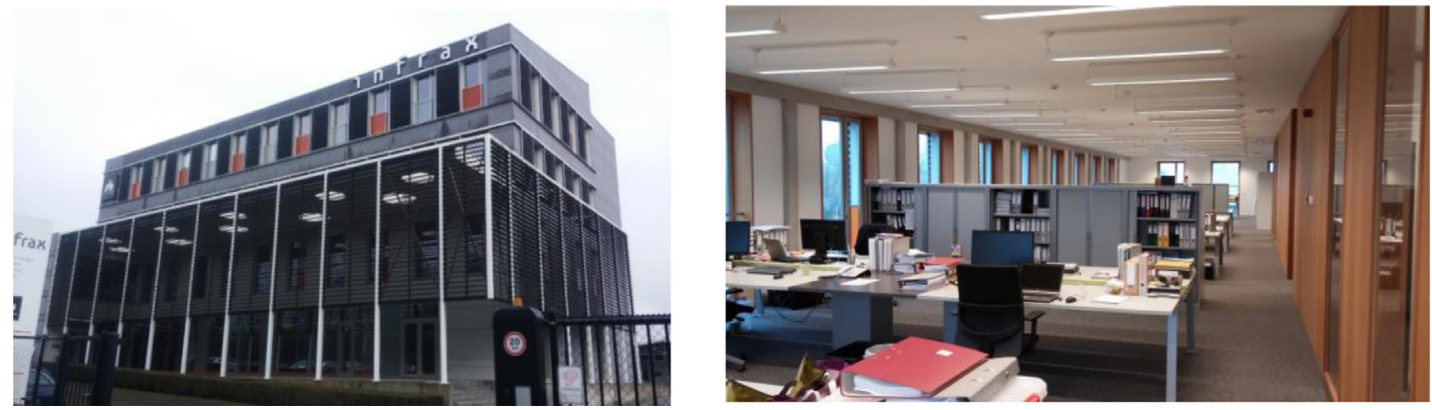

Fig. 5. Impression of the Infrax office building and landscaped office. 


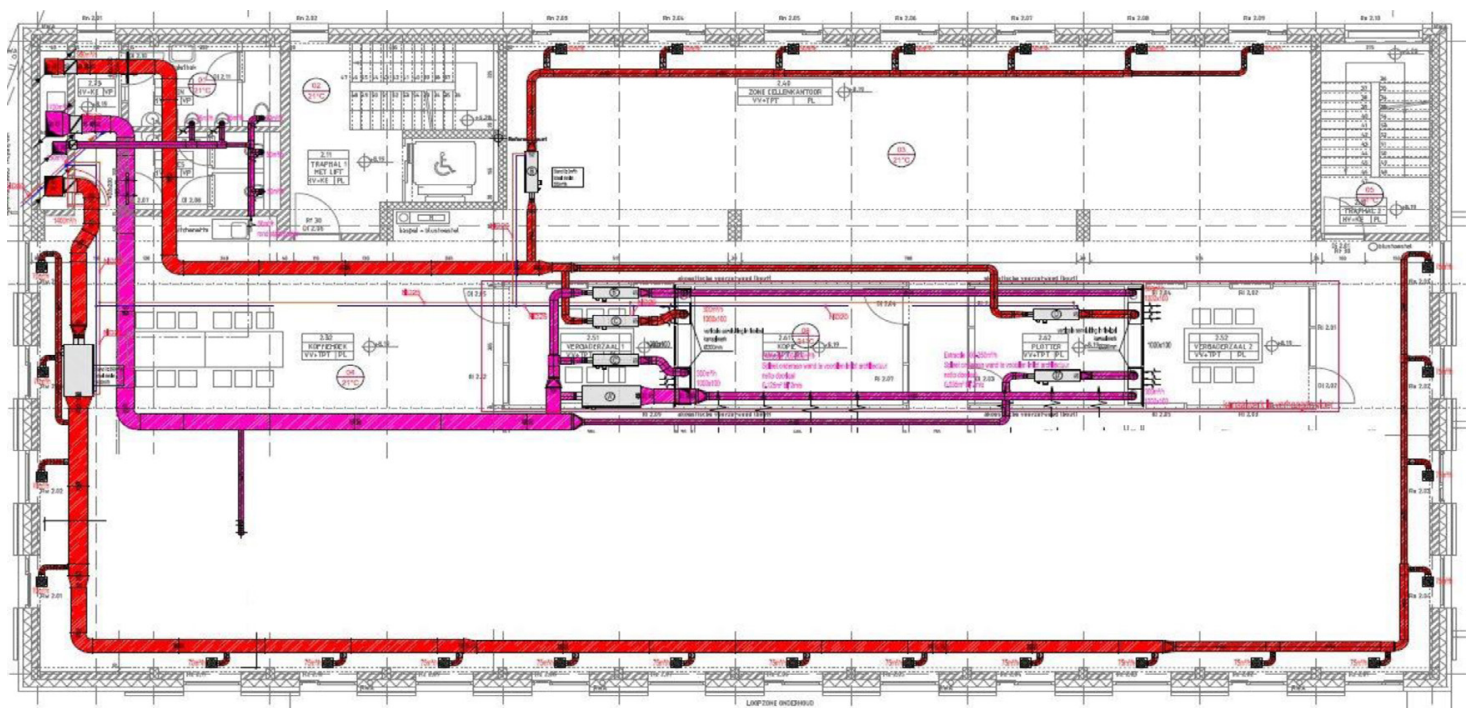

Fig. 6. Plan of the measured office zone.
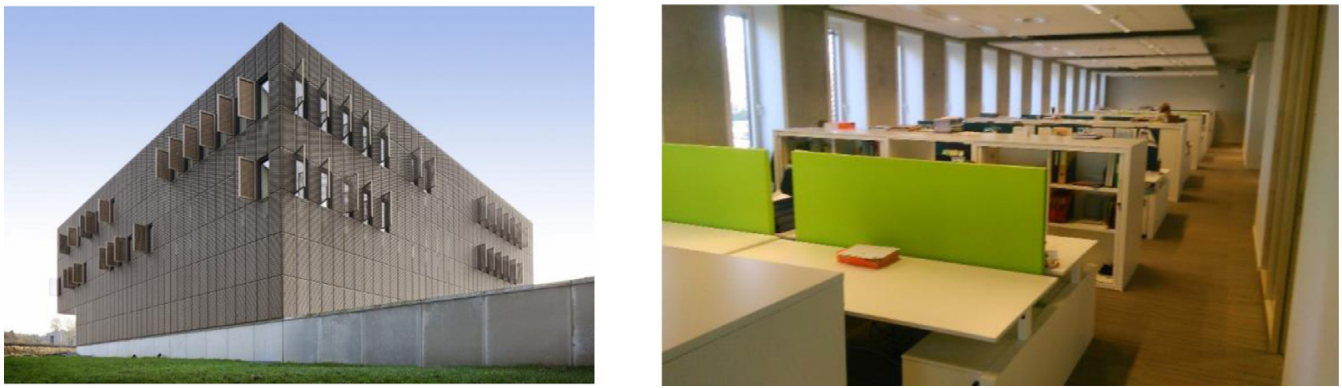

Fig. 7. Impression of the KU Leuven office building and landscaped office.

Two landscaped offices, highlighted by the red rectangle in Fig. 8, with a design occupancy of 12 persons (both approximately $70 \mathrm{~m}^{2}$ ), each with a different orientation (north and southeast), are studied in detail. Balanced mechanical ventilation is provided, fresh air is supplied through swirl diffusers in the ceiling. Each landscaped office is a single zone with a supply and extract VAV. The supply VAV controls the air flow rate (70-420 in office 1 and 75$500 \mathrm{~m}^{3} / \mathrm{h}$ in office 2) based on the $\mathrm{CO}_{2}$ concentration and the operative temperature measured inside the extract air grill. Set points for the DCV system are maintained at $800 \mathrm{ppm}$ and $23.8^{\circ} \mathrm{C}$ (in summer the set point is set to $22^{\circ} \mathrm{C}$ ). For heating purposes, the air is preheated by an air-to-air heat recovery. Additionally, a heating coil is integrated in the supply ducts of each zone (respectively 1.9 and $2.3 \mathrm{~kW}$ ) to control the maximum supply air temperature $\left(\mathrm{T}_{\text {supply;max }}: 40^{\circ} \mathrm{C}\right)$. A more detailed description of this case study can be found in De Klerck and Massagé [4].

The AHU is switched on from Tuesday to Friday at $04: 15 \mathrm{~h}$ and switched off at 18:00 h. During the beginning of the week the AHU is already switched on at Sunday 22:00 h to warm up the zone for the next day. The early start up time is chosen due to the high heating demand to meet the required heating set point of $23,8^{\circ} \mathrm{C}$. The building is in use from Monday to Friday during work hours, which is $8: 00 \mathrm{~h}-18: 00 \mathrm{~h}$.

\section{Method}

Measurements have been performed in the period from end 2015 to end 2016. In each case study measurements are conducted for at least two consecutive weeks. Parameters that have been analysed are $\mathrm{CO}_{2}$ concentration, air temperature (zone, supply) and

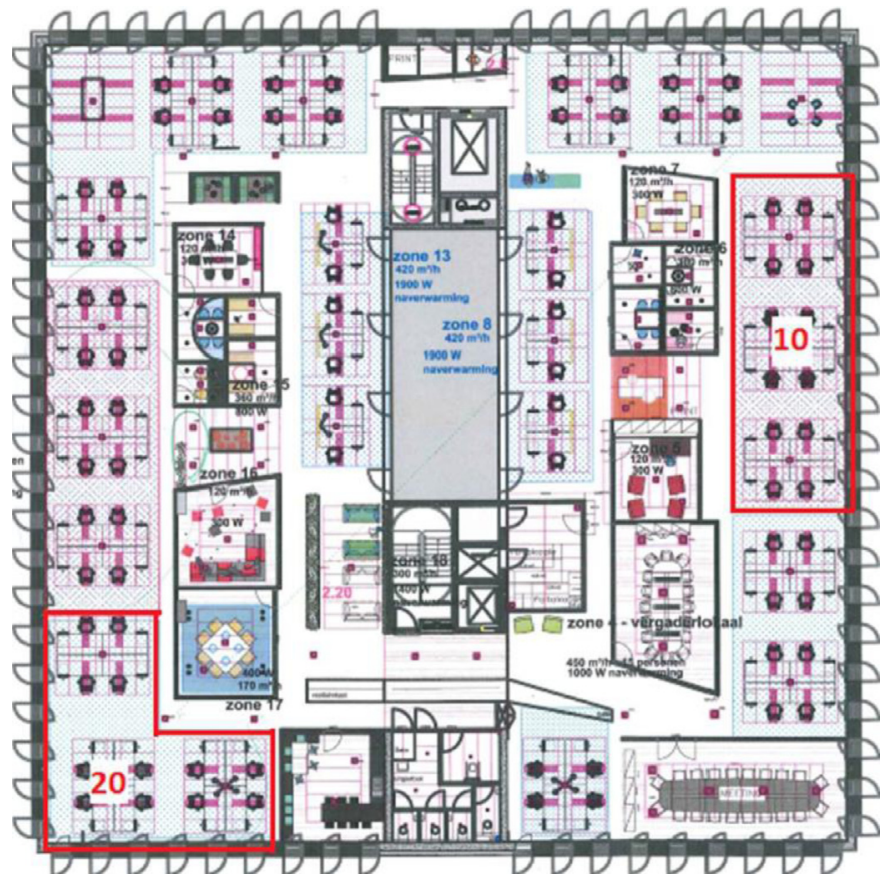

Fig. 8. Plan of the first floor, zone 10 and zone 20 are the zones analyzed. (For interpretation of the references to color in this figure legend, the reader is referred to the web version of this article.)" 
Table 3

\begin{tabular}{ll} 
IDA class [6]. & \\
\hline IDA class & $\mathrm{CO}_{2}$ concentration above outdoor $(\mathrm{ppm})$ Range \\
\hline IDA 1 & $<400$ \\
IDA 2 & $400-600$ \\
IDA 3 & $600-1000$ \\
IDA 4 & $>1000$ \\
\hline
\end{tabular}

VAV damper position in order to evaluate the IAQ ventilation efficiency and the energy efficiency of the ventilation system.

\subsection{Indoor air quality (IAQ)}

To evaluate the IAQ $\mathrm{CO}_{2}$ concentrations are measured inside the occupied zone at different positions. The IAQ is assessed with use of the classification as proposed in the European standard [6] which is based on the $\mathrm{CO}_{2}$ concentration in the room above the outdoor concentration, i.e. the InDoor Air (IDA) classes as shown in Table 3.

\subsection{Ventilation efficiency}

A second important parameter to assess the performance of the DCV is the ventilation efficiency. This parameter indicates if the supply air is distributed well inside the zone. The ventilation efficiency is defined by Eq. (1) according to EN 13779 [6].

$\varepsilon_{v}=\frac{C_{E T A}-C_{S U P}}{C_{I D A}-C_{S U P}}$

In which $\varepsilon_{\mathrm{V}}$ is the ventilation efficiency, $\mathrm{C}_{\mathrm{ETA}}$ the $\mathrm{CO}_{2}$ concentration of the extraction air, $\mathrm{C}_{\mathrm{IDA}}$ the $\mathrm{CO}_{2}$ concentration in the occupancy zone and $\mathrm{C}_{\mathrm{SUP}}$ the $\mathrm{CO}_{2}$ concentration of the supply air.

For a good operating and well-designed ventilation system the ventilation efficiency has to be between 0,70 and 1,10 according to guidelines given in EN 13779 [6]. For displacement ventilation systems values between 1-2 are more common.

\subsection{Energy efficiency}

For energy efficiency both saving on the fan energy and the heat losses are analyzed. The ventilation heat losses will be used to evaluate the energy savings for the heating system that is incorporated in the DCV. The ventilation heat losses are calculated using Eq. (2). This gives an indication of the heating energy demand which can be used to compare DCV to a CAV system.

$$
\begin{aligned}
& Q= 0.34 * q * \Delta T \\
& \mathrm{Q}=\text { heat losses }(\mathrm{W}) \\
& \mathrm{q}=\text { air flow }\left(\mathrm{m}^{3} / \mathrm{s}\right) \\
& \Delta \mathrm{T}=\mathrm{T}_{\text {supply air }}-\mathrm{T}_{\text {air after heat-exchanger }}(\mathrm{K})
\end{aligned}
$$

To compare DCV to a CAV system the air flow rate for CAV is based on the measured occupancy and the default value for the air flow rate/person based on IDA class 3 in EN 13779 [6] (i.e. $29 \mathrm{~m}^{3}$ h.pers).

For the fan energy consumption the savings are compared to a CAV system with an air flow rate which is similar to the air flow used for ventilation heat losses (i.e. $29 \mathrm{~m}^{3} /$ h.pers). In two case studies (Boomhut and test lecture rooms) the fan power consumption is monitored while in the KU Leuven office simulations are performed to calculate the fan energy savings. For the Infrax case no data was available to calculate the fan power consumption.

\subsection{Measurement set up}

Measurements are carried out during occupied hours for a period of at least two consecutive weeks for each case study during autumn/winter between November 2015 and December 2016. The monitoring in the rooms is carried out by means of a central PLC system, a Beckhoff CX9020. Several types of terminals are connected via EtherCAT to the PLC. The embedded PC runs 1 monitoring application for gathering data from each sensor.

To monitor the IAQ and ventilation efficiency, a minimum of 2 $\mathrm{CO}_{2}$ sensors are installed in the occupied zone and 1 at the extract air grill. The measurement set-up for each case study is shown in Figs. 9-11. For example, in the measurement setup for the Infrax case $6 \mathrm{CO}_{2}$ sensors were used and installed on the work stations. The already installed $\mathrm{CO}_{2}$ sensor (BMS) is located at the extract air grill and is used for controlling the VAV damper position.

Properties of the sensors used for these measurements are listed in Table 4. Time interval used for the IAQ and ventilation efficiency measurements in all case studies is $1 \mathrm{~min}$. The measurement height used for the $\mathrm{CO}_{2}$ sensors inside the occupied zone is between $0.80-1.50 \mathrm{~m}$ high.

For energy efficiency the data of the BMS is used to monitor temperatures for supply air and temperature after heat exchanger. This data is used to calculate the heat losses. The position of the VAV damper, monitored in the BMS, is used to calculate the
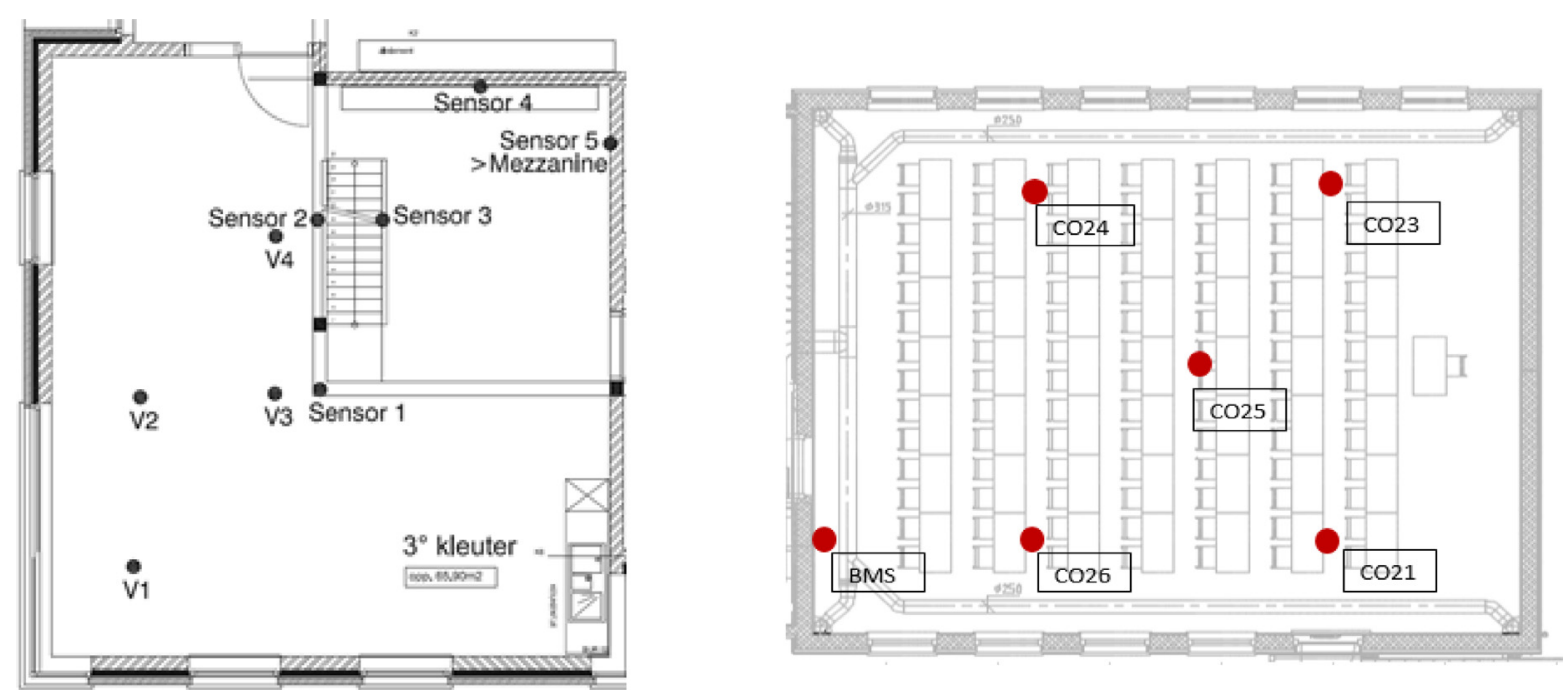

Fig. 9. Measurement setup (left) for $\mathrm{CO}_{2}$ sensors (sensor 1-5) and velocity sensors (V1-V4) in De Boomhut and (right) for the test lecture rooms. 


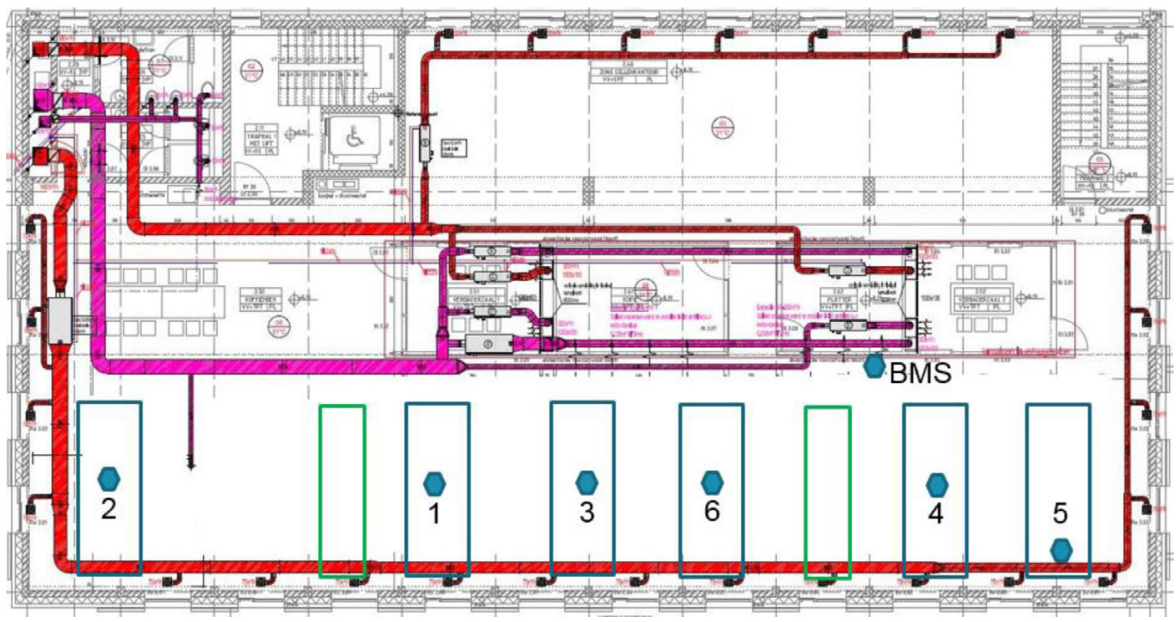

Fig. 10. Measurement setup used during evaluation in landscape office of Infrax.
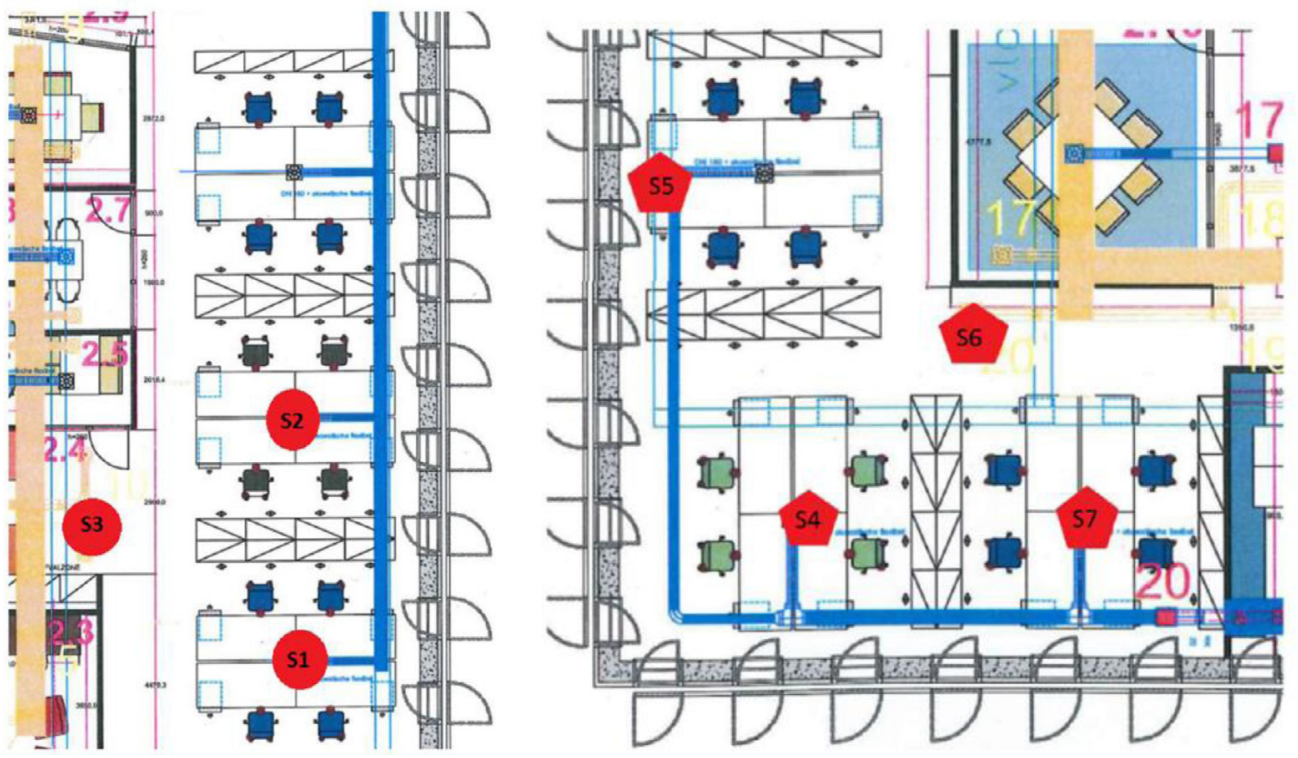

Fig. 11. KU Leuven office measurement setup, (Left) zone 10 (Right) zone 20.

Table 4

Properties of the sensors used for measurements.

\begin{tabular}{lll}
\hline Parameter & Type sensor & Accuracy \\
\hline Air temperature & Omega PT100 & $\pm 0,10{ }^{\circ} \mathrm{C}$ \\
$\mathrm{CO}_{2}$ concentration & VAISALA GMW 94 & $\pm 30 \mathrm{ppm}+2 \%$ of reading \\
& Telaire 700LI & $\pm 50 \mathrm{ppm}+5 \%$ of reading \\
Occupancy & Crosscan Camera 3D & $7 \% \pm 2 \%$ or (absolute \pm 2 persons) \\
\hline
\end{tabular}

air flow rate. Additionally, to evaluate the operation of the AHU measurement data of the available BMS is used. For fan power consumption data is measured (Boomhut and test lecture room) or simulated (case KU Leuven office). For the Dilbeek case study, no data was available for fan power consumption.

Room occupancy is measured by manually counting the number of people or by using counting cameras in the case of the Test lecture room. In the lecture room near the entrance Crosscan $3 \mathrm{D}$ counting cameras are installed in the ceiling. They are the type of cameras usually installed in shops to count the number of visitors.

\section{Results and discussion}

\subsection{Operation of ventilation system}

To give a general picture of demand controlled ventilation, the operation of two well-chosen examples is included. Fig. 12 illustrates the AHU in Infrax office building that mainly operates at minimum air flow rate. Second, Fig. 13 shows the AHU in the test lecture rooms of KU Leuven with a more fluctuating air flow. A detailed description of the operation of the system in the Boomhut case can be found in Merema et al. [15] and of KU Leuven office in De Klerck and Massage [4]. In all these cases it is shown that the air flow increases when the $\mathrm{CO}_{2}$ or the temperature set point is exceeded. During hours with low or no occupancy, the air flow decreases to a minimum to reduce energy consumption for the fans. The operation of the DCV is case specific since the design of the ventilation system in each building is different. Also the operation of the $\mathrm{AHU}$ is influenced by the predefined set points (e.g. $\mathrm{CO}_{2}$ and zone temperature) which are case specific.

In contrast to the other studies, the Infrax case indicates that the system operates at a minimal air flow rate for a large part of the measurement period (approximately 67\% of the time 


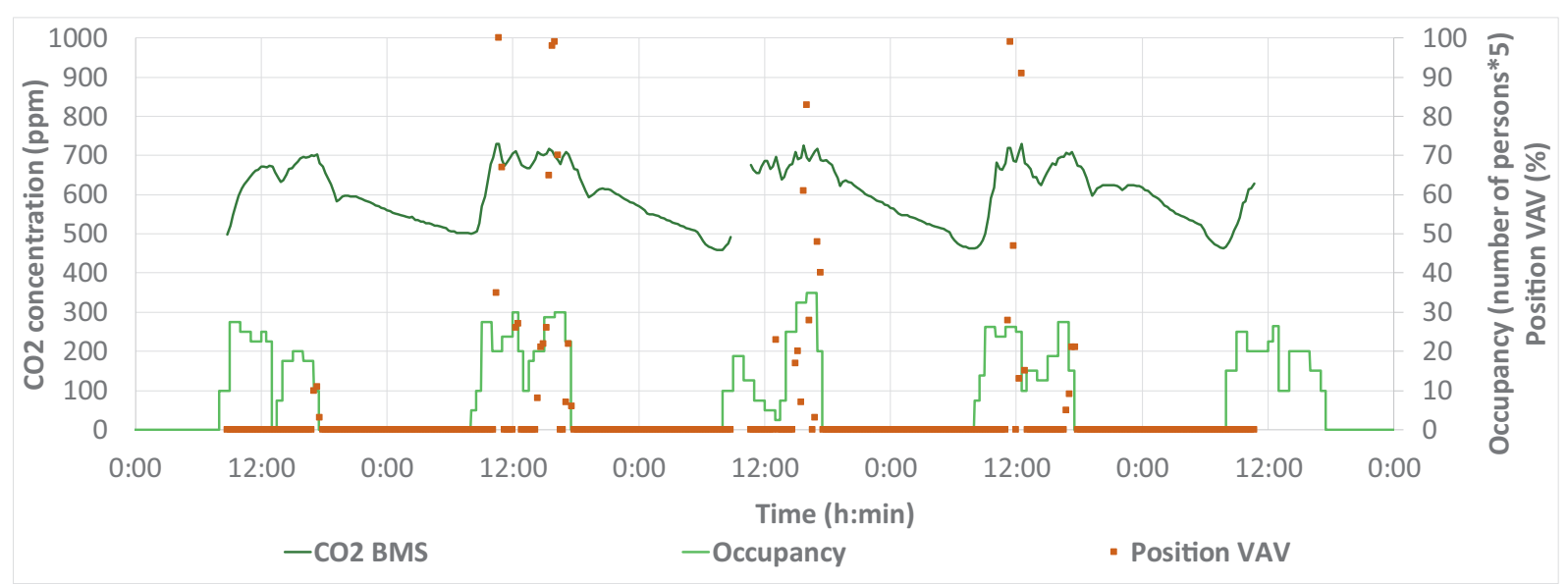

Fig. 12. Operation of the AHU for Infrax (29 February-4 March 2016).

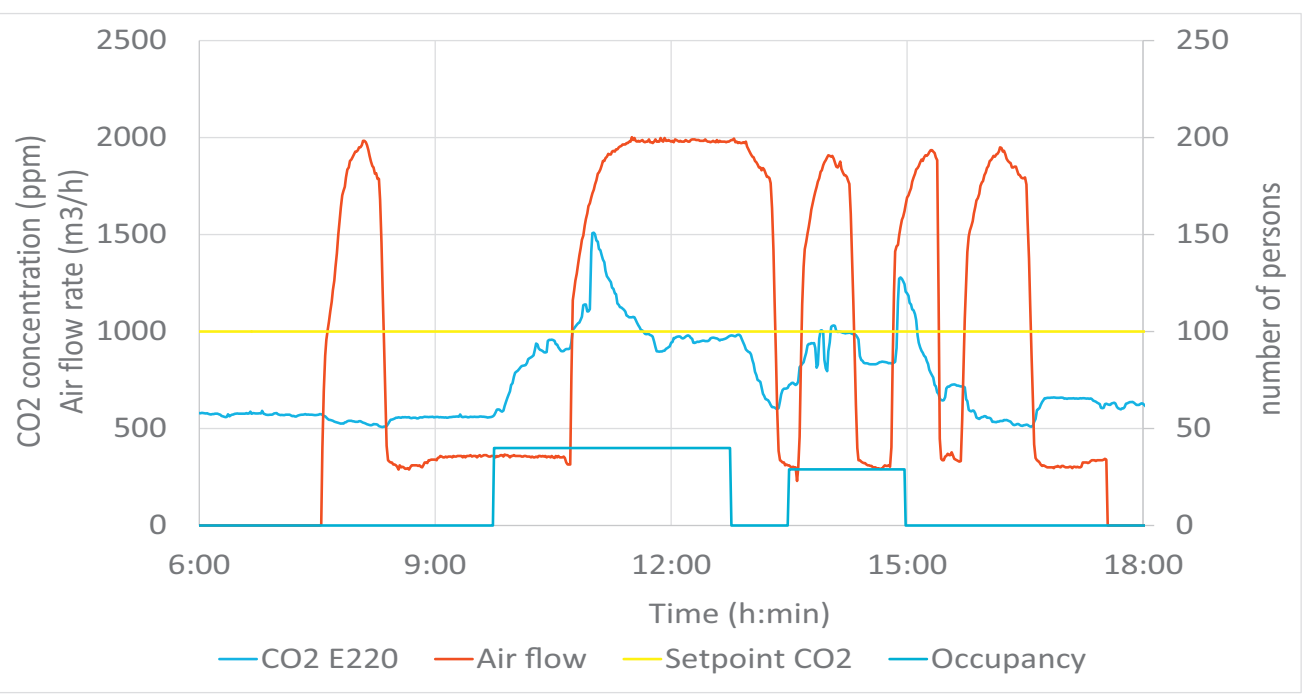

Fig. 13. Operation of the AHU for the test lecture rooms (18th of March 2016).

during operating hours). This was a result of a low occupancy rate compared to the minimal air flow rate (maximum 7 persons with minimal air flow rate of $550 \mathrm{~m}^{3} / \mathrm{h}$ ).

In Fig. 13 it is shown that the air flow rate is also increased for heating of the zone. During the start-up of the AHU, the air flow increases to a maximum air flow rate to meet the set point for the zone temperature. When the zone temperature exceeds to the set point, the air flow decreases to a minimum air flow rate. In the KU Leuven landscape offices the operation of the AHU was influenced by the high heating demand due to the set point of $23,8^{\circ} \mathrm{C}$. While in the Boomhut case study the operation was mainly influenced by the occupancy.

\subsection{IAQ}

Fig. 14 shows the results of the measurements for $\mathrm{CO}_{2}$ concentrations inside the zone and the $\mathrm{CO}_{2}$ concentration measured by the $\mathrm{CO}_{2}$ sensor that controls the DCV system. The results are limited to operating hours of the AHU for each case study building. The box presents the $25-75 \%$ percentiles of all measured values during operating hours of the AHU.

It can be noticed that the majority of the $\mathrm{CO}_{2}$ concentration was below $1000 \mathrm{ppm}$ which in its turn can be related to the fact that most $\mathrm{CO}_{2}$ set points used were $1000 \mathrm{ppm}$ or lower. The only excep- tion is the Boomhut case where the $\mathrm{CO}_{2}$ set point was $1100 \mathrm{ppm}$. However, during short periods some increased values (>1400 ppm), i.e. much larger than the set point value, were measured in the Test lecture rooms and the Boomhut. Maximum values measured in these cases were up to $2000 \mathrm{ppm}$. Most of these high values were a result of students very close to a sensor, since these values were only measured for a short time period ( $<2 \mathrm{~min}$ ). Furthermore, it can be seen that the median values for all the sensors installed in the zone show variations of approximately $100 \mathrm{ppm}$, which indicates that the $\mathrm{CO}_{2}$ concentration inside the zone is well distributed since no large variations are shown between the different installed $\mathrm{CO}_{2}$ sensors inside the zone.

Fig. 15, presents the results of the $\mathrm{CO}_{2}$ measurements during operating hours for both the sensor installed in the occupied zone (sensor with highest values) and the sensor located at the extraction air. In all the case studies for the outdoor $\mathrm{CO}_{2}$ concentration a default value of $430 \mathrm{ppm}$ was assumed for the calculations of the IDA class.

In the Infrax office the IAQ is equal to IDA class 1 [6], indicating that the IAQ is the highest possible class that can be achieved. The results show that the DCV system is able to deliver a good IAQ. The IAQ in the Boomhut and the test lecture rooms is comparable to IDA class 3, which is the basis level for an acceptable IAQ. The higher IDA class can be related to the higher $\mathrm{CO}_{2}$ set points 

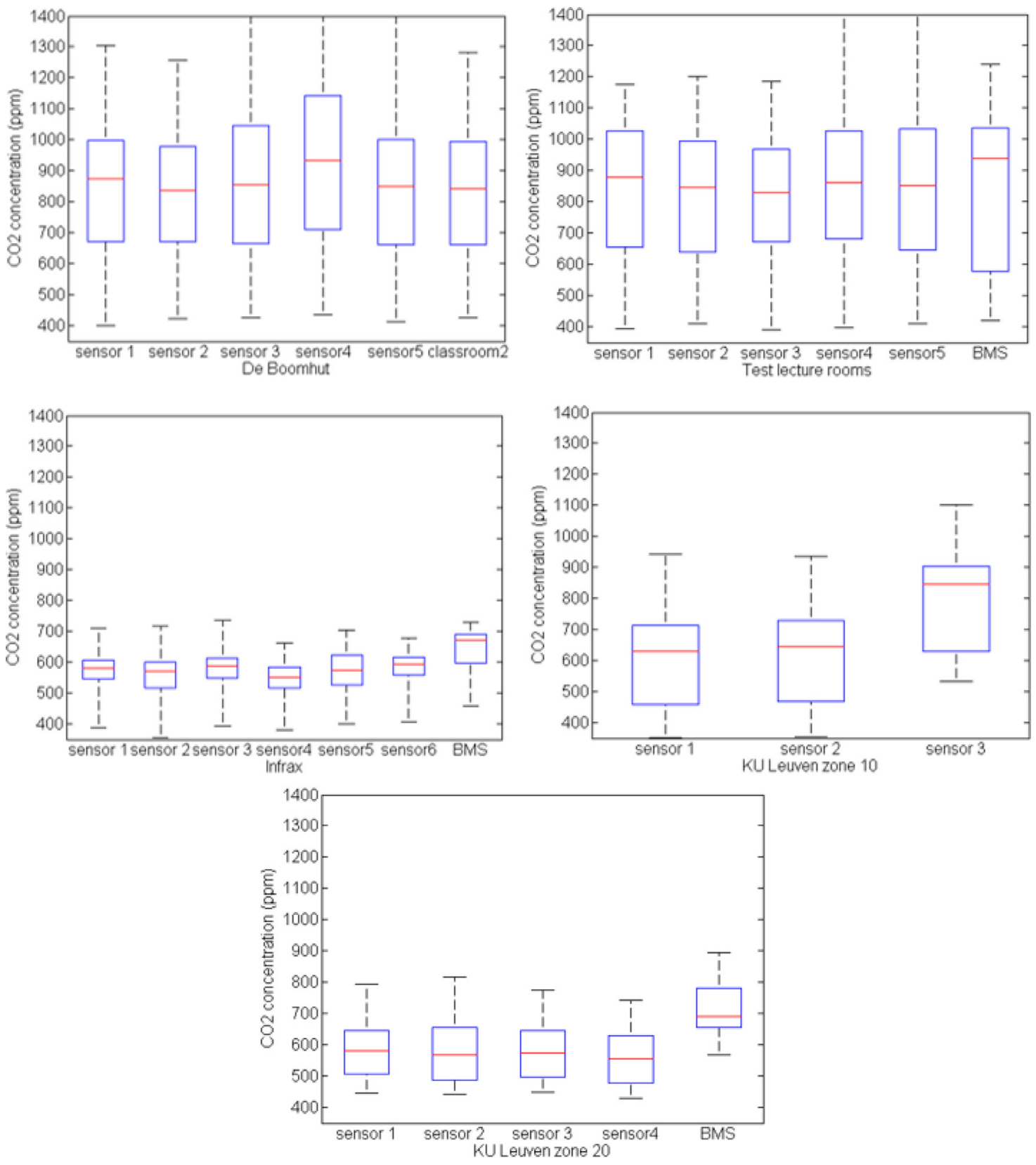

Fig. 14. $\mathrm{CO}_{2}$ measurement data during operating hours for the case studies evaluated.

chosen in these studies, respectively $1000 \mathrm{ppm}$ and $1100 \mathrm{ppm}$. The two offices of the KU Leuven building are in IDA class 1 which can be related to the chosen $\mathrm{CO}_{2}$ set point of $800 \mathrm{ppm}$. An explanation is that in the measured zones the occupancy density was low, most of the time the occupancy rate was below $50 \%$. Furthermore, it is noticed that in most ( 3 out of 5) case studies the $\mathrm{CO}_{2}$ concentration in the occupied zone is at least $100 \mathrm{ppm}$ lower than at the extraction air grill, which indicates a good operation of the ventilation system.

\subsection{Ventilation efficiency}

The ventilation efficiency of the system is determined based on the $\mathrm{CO}_{2}$ data of the sensor installed in the occupied zone (sensor with highest measured $\mathrm{CO}_{2}$ values) and the sensor at the extract air by using Eq. (1) with the maximum measured values. Table 5 lists the results for ventilation efficiency for all the case studies during operating hours and shows how the fresh air is supplied. The value presented is an average value for the complete measurement period, the standard deviation is also indicated.

It can be seen in Table 5 that for all the case studies analysed, the ventilation efficiency is between 0,89 and 1,50 . These numbers clearly indicate that in all cases measured the DCV system is working as efficiently as designed. Both the test lecture rooms and the Infrax case show an efficiency of approximately 1,50. The high efficiency can be explained by the fact that the test lecture rooms uses displacement ventilation while in Infrax air is supplied via the floor at low air speed. For the KU Leuven offices it can be seen that there is a difference of 0,35 in ventilation efficiency. The difference can be explained by the fact that in office 2 the occupancy rate was higher compared to office 1 which resulted in higher $\mathrm{CO}_{2}$ concentrations inside the occupied zone.

A good operating and well-designed ventilation system should have a good ventilation efficiency between 0,70 and 1,10 . All the 


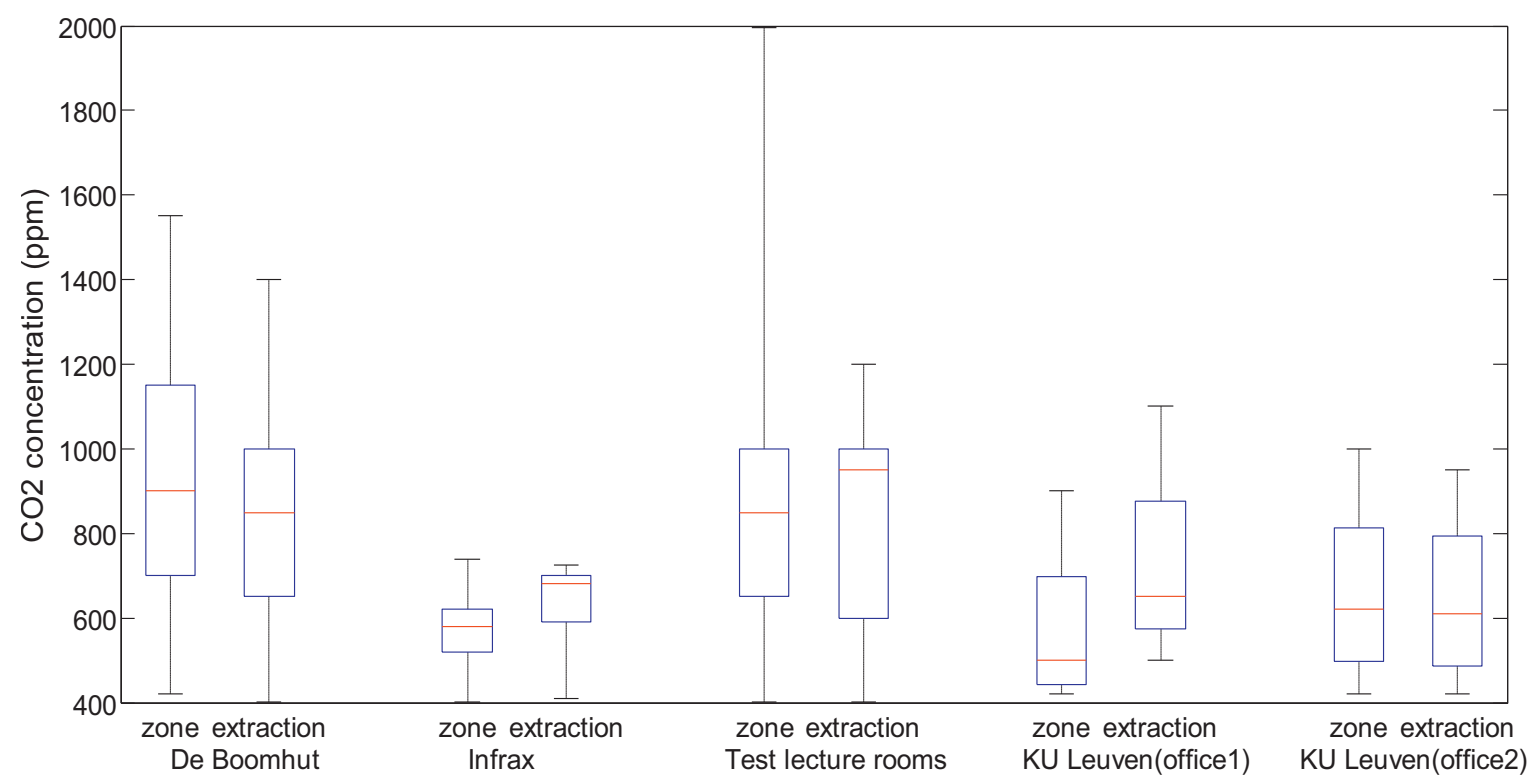

Fig. 15. $\mathrm{CO}_{2}$ concentrations during operating hours for all case studies.

Table 5

Ventilation efficiency.

\begin{tabular}{llll}
\hline Case study & $\begin{array}{l}\text { Ventilation efficiency } \\
\text { (std. dev.) }\end{array}$ & Air Supply & $\begin{array}{l}\text { Occupancy rate } \\
\text { (actual/design occupancy) }\end{array}$ \\
\hline De Boomhut & $0,89(0,32)$ & Grill above windows & 0,75 \\
Infrax & $1,50(0,27)$ & Air supply in floor & 0,20 \\
Test lecture rooms & $1,49(0,55)$ & $\begin{array}{l}\text { In each corner of the room an } \\
\text { air grill (displacement }\end{array}$ & 0,48 \\
KU Leuven office & 1,27 (office 1) & ventilation) & \\
& 0,92 (office 2) & Air supply in ceiling (swirl diffuser) & 0,42 \\
& & & 0,33 \\
\hline
\end{tabular}

Table 6

Reduction in fan energy and heat losses for DCV compared to CAV.

\begin{tabular}{lllll}
\hline Case study & Fan energy $(\%)$ & Ventilation heat losses(\%) & Heating degree days $\left(\mathrm{T}_{\text {ref }}: 16,5^{\circ} \mathrm{C}\right)$ & Minimal air flow time $(\%)$ \\
\hline De Boomhut & 50 & 36 & Nov 2015: 192 & 39 \\
Infrax & - & - & - & 67 \\
Test lecture rooms & 55 & 47 & Feb 2016: 346 & 20 \\
KU Leuven office & 50 & 34 & Dec 2016: 365 & 0
\end{tabular}

a Energy consumption and heat losses were not measured in this case study. However, the ventilation system operated 67\% of the time during operating hours on a minimum airflow which indicates an energy saving potential.

evaluated studies show values which correspond to the afore mentioned values. These results show that DCV is able to provide a good ventilation efficiency and is operating as designed. In addition, in all the case studies the maximum measured $\mathrm{CO}_{2}$ concentration (worst case scenario) is used to calculate the ventilation efficiency.

\subsection{Energy efficiency}

The total fan energy demand and ventilation heat losses for the complete measurement period are calculated while savings are shown in Table 6. Energy reductions for both fan and heat losses are compared to the design occupancy with an air flow rate of $29 \mathrm{~m}^{3} / \mathrm{h}^{*}$ pers. Heat losses, due to ventilation, are calculated based on the air flow rate and the temperature difference between zone and supply air temperature after heat exchanger (or in case of natural supply, the outdoor temperature). Furthermore, to have an indication of the energy demand for heating, the heating degree days
[5] are indicated for the complete month during the measurement period.

In all the cases, it is shown that significant energy reductions can be achieved by implementing a DCV system. In all case studies reductions on the fans are at least $50 \%$ and on heat losses $34 \%$. Highest reductions are found for the fans with a maximum of $55 \%$ for the test lecture rooms case. The lowest was found for the office building of KU Leuven with $50 \%$, which still is a significant energy reduction. For heat losses the reductions are minimum 34\% (KU Leuven office) and maximum $47 \%$ (Test lecture rooms).

The test lecture rooms showed the largest reductions for both fan and heat losses. The reduction was mainly attributed by the varying occupancy rate both in time and group size (20-80 persons). The heat losses in the KU Leuven office are the lowest because of a high heating demand since the set point used for heating was $23,8^{\circ} \mathrm{C}$. For the Boomhut the savings for both the fan and the ventilation heat losses is affected by the less varying occupancy rate inside the classroom. 
Table 7

Reduction in fan energy and heat losses and use of lecture room.

\begin{tabular}{lllllllll}
\hline & Nov & Dec & Feb & March & May & June & Sep & Oct \\
& 2015 & 2015 & 2016 & 2016 & 2016 & 2016 & 2016 & 2016 \\
\hline Fan energy savings (\%) & 57 & 64 & 62 & 74 & 40 & 48 & 42 & 75 \\
Ventilation heat losses (\%) & 46 & 56 & 47 & 68 & 46 & 33 & 32 & 69 \\
Number of people (median) & 45 & 30 & 36 & 40 & 22 & 20 & 30 & 55 \\
Occupancy hours (h) & 83 & 62 & 43 & 35 & 44 & 9 & 60 & 77 \\
\hline
\end{tabular}

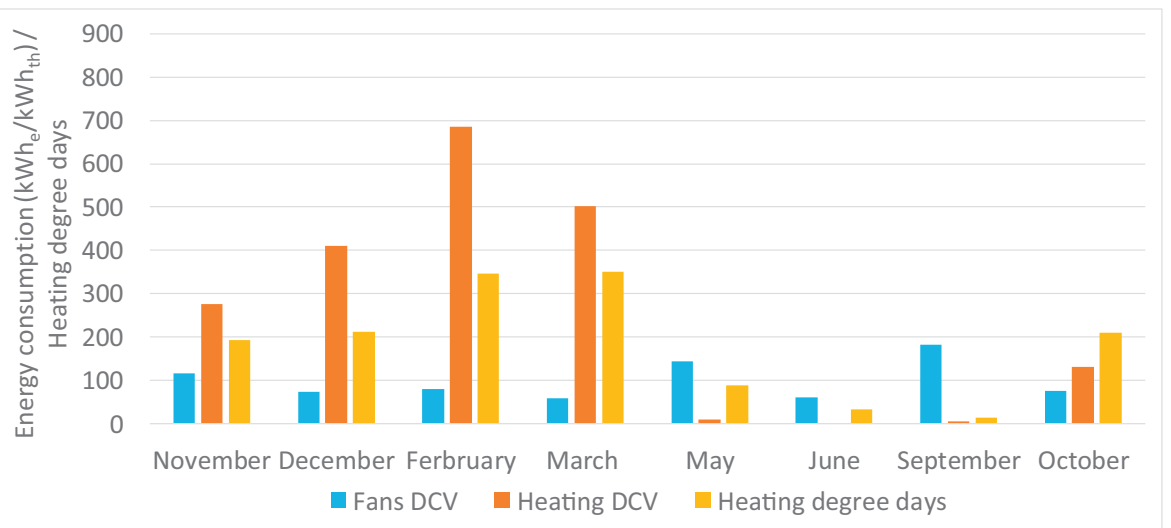

Fig. 16. Energy consumption for the measured test lecture room during one year (November 2015-October 2016).

The results presented in Table 6 are in line with the reduction achieved for both fan energy and ventilation heat losses in previous studies, listed in Table 1 . As in previous studies fan energy savings are slightly higher than the heating savings. Furthermore, savings of approximately $50 \%$ on fan energy use are comparable to the majority of the previous studies in Table 1. This indicates that climate does not have a high impact on the expected fan energy savings. Only two of these previous studies give data about savings in ventilation heat losses. Compared to these studies it is shown that the savings of heat losses in a moderate climate are approximately $15 \%$ higher compared to these in a cold climate [25].

In addition to these energy efficiency results, Table 7 and Fig. 16 show measurement data of fan energy use and ventilation heat losses in the Test lecture rooms for one year (November 2015 October 2016). Since there were no classes during April, July and August and only a few hours in January due to exams, these data are excluded from the analysis. Table 7 depicts fan energy savings between $40-75 \%$. Fig. 16 clearly shows that the hours in use by occupants affect both the fan energy consumption and the savings. Additionally, during the warmer months (May, June and September) fan energy consumption is higher and savings are restricted compared to the colder months, approximately 40-48\% compared to over $60 \%$ for the colder months. With a higher outdoor temperature, the system activates the indirect evaporative cooling and increases the air flow rate to maximum, resulting in a higher fan energy consumption. During the warmer months, the evaporative cooling system operated for 23\% (May) up to 55\% (September) of the operating hours. For ventilation heat losses results show savings between $32-69 \%$. However, there is no clear relation between the heating degree days and the savings in ventilation heat losses.

\section{Conclusions}

The aim of the present study consisted in both evaluating the energy savings on heating and fans combined with the effect on the IAQ for DCV systems in real buildings while using measurement data. Measurements were performed in five different rooms in school and office buildings for two consecutive weeks during a period with heating demand.
The measurement results show that in all the case studies the DCV system was able to deliver and maintain a good IAQ even at reduced air flow rates. The VAV dampers or extract fans respond well to predefined set points of $\mathrm{CO}_{2}$ concentration and temperature. Even at low air flow rates, it was noticed that the ventilation efficiency was not affected. This shows that demand controlled ventilation is effective in distributing the air even at reduced air flow rates.

The measurements also showed a significant difference in $\mathrm{CO}_{2}$ concentration was noticed between the occupied zone and the extraction air grill. This shows that the position of the $\mathrm{CO}_{2}$ sensor, which controls the airflow, is important for the operation of the DCV.

Results of the case studies shows that significant reductions in energy consumption are achieved for both the fans (50-55\%) and ventilation heat losses (34-47\%). This means that DCV has a high energy saving potential for rooms with a varying occupancy profile, both in size and time, such as landscaped offices and lecture rooms.

However, the measurements revealed some unexpected performances and errors. The ventilation system in the Infrax office building was noticed to operate during $67 \%$ of the time at the minimum airflow rate. This could indicate that the minimal airflow rate is too high compared to the actual occupancy. For designers of DCV systems it is therefore advised to design the minimum and maximum air flow rate according to a realistic occupancy to avoid oversizing. In the test lecture rooms the position of the $\mathrm{CO}_{2}$ sensor was changed because first results of ventilation efficiency indicated a large difference between $\mathrm{CO}_{2}$ measured at the extract air grill and the occupied zone. The sensor was installed at the wall just above the extraction grill which resulted in high measured $\mathrm{CO}_{2}$ concentrations for this position compared to the values measured in the occupied zone. This proves that care should be taken when choosing the position of the $\mathrm{CO}_{2}$ and temperature sensor. When the position of the sensor is not carefully chosen, the IAQ and thermal comfort might be affected since the measured values are not in line with the indoor climate sensed by the occupants. In the case studies the $\mathrm{CO}_{2}$ concentration was measured near the 
extract air grill and showed good correspondence to the $\mathrm{CO}_{2}$ concentration measured in the zone near the occupants. In addition, set point values should be chosen carefully to obtain a good performance (e.g. $800 \mathrm{ppm}$ in offices and $1000 \mathrm{ppm}$ in classrooms). As a consequence, commissioning is necessary to obtain and guarantee a good energy efficiency and IAQ performance of an DCV system.

\section{Acknowledgments}

This research is funded by Flanders Innovation and Entrepreneurship (VLAIO). This support is gratefully acknowledged. TETRA 140345: "Optimisation of demand controlled ventilation in nZEB commercial buildings". Furthermore the support of the involved companies in the TETRA project is gratefully acknowledged.

\section{References}

[1] K. Ahmed, J. Kurnitski, P. Sormunen, Demand controlled ventilation indoor climate and energy performance in a high performance building with air flow rate controlled chilled beams, Energy Build. 109 (2015) 115-126.

[2] H. Breesch, B. Wauman, R. Klein, A. Versele, Design of a new NZEB test school building, REHVA J. (2016) 2016 January.

[3] N. Brelih, O. Seppänen, O. Bertilsson, M.L. Maripuu, H. Lamy, A Vanden Borre, Design of energy efficient ventilation and air-conditioning systems, REHVA (2012) guidebook no 17.

[4] L. De Klerck, G. Massagé, Evaluation of the Indoor Climate and the Operation of a Demand Controlled Ventilation System in an Office Building MSc Thesis, KU Leuven Technologiecampus Gent, 2017.

[5] Degree days, Synergrid graaddagen, 2017. Retrieved from http://www. synergrid.be/index.cfm?PageID=17601\&language_code=NED.

[6] EN 13779, Ventilation for Non-Residential Buildings - Performance for Ventilation Androom-Conditioning Systems, CEN, Brussels, 2010.

[7] EnBau, Performance of buildings across the year, 2010. Retrieved from http://www.enob.info/en/analysis/analysis/details/ performance-of-buildings-across-the-year/.

[8] W.J. Fisk, M.J. Mendell, M Davies, E. Eliseeva, D. Faulkner, T. Hong, D.P. Sullivan, Demand Controlled Ventilation and Classroom Ventilation, Lawrence Berkeley National Laboratory, 2012 LBNL 6563E.

[9] Geotabs, Geotabs Infrax Dilbeek, 2018. Retrieved from https://www.geotabs.eu/ Database/Buildingflyer_InfraxDilbeek_120921.pdf.

[10] ISO 7730, Ergonomics of the Thermal Environment - Analytical determination and Interpretation of Thermal Comfort Using Calculation of the PMV and PPD Indices and Local Thermal Comfort Criteria, ISO, 2005.
[11] J. Kolarik, J. Toftum, M. Kabrhel, F. Jordan, O. Geiss, K. Kabele, Field measurements of perceived air quality and concentration of volatile organic compounds in four offices of the university building, Indoor Built Environ. 0 (0) (2014) 1-11.

[12] M. Kottek, J. Grieser, C. Beck, B. Rudolf, F. Rubel, World map of the Köppen-Geiger climate classification updated, Meteorol. Z 15 (2006) 259-263.

[13] M.L. Maripuu, Demand Controlled Ventilation (DCV) Systems in Commercial buildings: Functional Requirements on Systems and Components, School of Electrical and Computer Engineering, Chalmers tekniska högskola, Göteborg, $2009 \mathrm{PhD}$.

[14] M.J. Mendell, G.A. Heath, Do indoor pollutants and thermal conditions in schools influence student performance? A critical review of the literature, Indoor Air 15 (1) (2005) 27-52.

[15] B. Merema, H. Breesch, M. Sourbron, Impact of demand controlled ventilation on indoor air quality, ventilation effectiveness and energy efficiency in a school building, Indoor Air 2016 (2016) 3-8 Gent, BelgiumJuly 2016.

[16] B. Merema, H. Breesch, M. Sourbron, J. Verplaetsen, P. Van den Bossche, Demand controlled ventilation in practice: Case study. Effective ventilation in high performance buildings, in: AIVC conference, Madrid, 2015, p. 2015. 22-23 September.

[17] M. Mysen, S. Berntsen, P Nafstad, P.G Shild, Occupancy density and benefits of demand-controlled ventilation in Norwegian primary schools, Energy Build. 37 (2005) 1234-1240.

[18] L. Pérez-Lombard, J. Ortiz, C. Pout, A review on buildings energy consumption information, Energy Build. 40 (3) (2008) 394-398.

[19] F.J. Rey Martínez, M.A. Chicote, A.V. Peñalver, A.T. Gónzalez, E.V. Gómez, Indoor air quality and thermal comfort evaluation in a Spanish modern low-energy office with thermally activated building systems, Sci. Technol. Built Environ. 21 (8) (2015) 1091-1099.

[20] O. Seppänen, W. Fisk, N. Lei, Ventilation and performance in office work, Indoor Air 16 (2006) (2006) 28-36.

[21] O. Seppänen, Effect of EPBD on future ventilation systems, REHVA J. (2012) 2012 February.

[22] V. Smith, J. Braun, Demand-Controlled Ventilation Assessment, California Energy Commission, 2003 Public Interest Energy Research.

[23] J. Stein, A. Zhou, H. Cheng, Advanced Variable Air Volume System Design Guide, California Energy Commission, 2007 Public Interest Energy Research.

[24] Z. Sun, S. Wang, Z. Ma, In-situ implementation and validation of a CO2-based adaptive demand-controlled ventilation strategy in a multi-zone office building, Build. Environ. 46 (1) (2011) 124-133.

[25] B.J. Wachenfeldt, M. Mysen, P.G. Schild, Air flow rates and energy saving potential in schools with demand-controlled displacement ventilation, Energy Build. 39 (2007) 1073-1079. 